\title{
CEREBROPULMONARY DYSGENETIC SYNDROME
}

D. Radford Shanklin, M.D., F.R.S.M.,,

Amanda C. Mullins, M.D., ${ }^{1}$ and

Heather S. Baldwin, M.D. ${ }^{1}$

Departments of Pathology and Laboratory Medicine ${ }^{\mathbf{1}}$ and

Obstetrics and Gynecology²

University of Tennessee, Memphis

Corresponding author:

D. Radford Shanklin, M.D., F.R.S.M.

Professor of Pathology and Laboratory Medicine

Professor of Obstetrics and Gynecology

University of Tennessee, Memphis

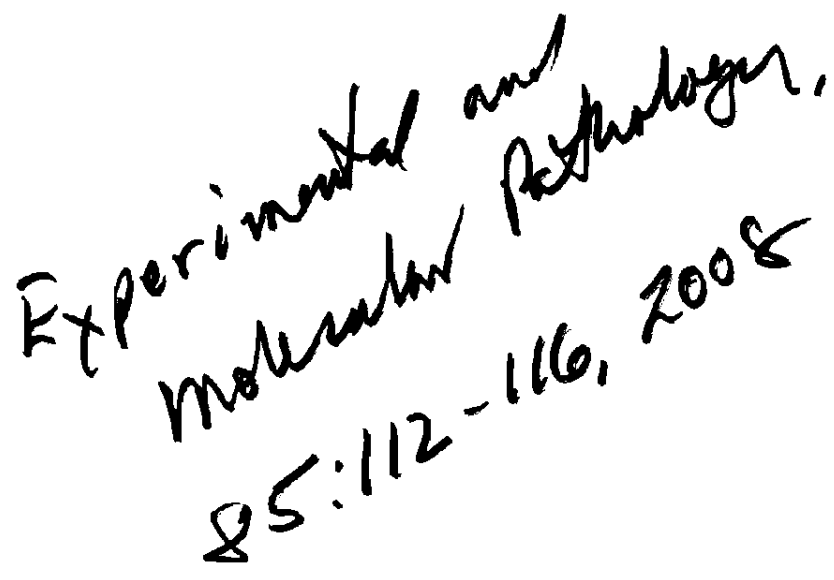

(Until June 30, 2008):

Department of Pathology and Laboratory Medicine

University of Tennessec, Memphis

930 Madison Avenue, Suite 599

Memphis, Tennessee 38163

Telephone: 901/448-6343; Facsimile: 901/448-6978

(After July 1, 2008):

Post Office Box 511

Woods Hole, Massachusetts 02543

Telephone: 508/457-0694; Facsimile: 508/457-9635

radfordcrawford@juno.com

University of Tennessee Perinatal Mortality Conference \#147,

11 December 2007 


\begin{abstract}
Ventilatory trcatment of neonatal respiratory distress often results in bronchopulmonary dysplasia from congenital surfactant deficiency due to mutants of transporter protein ABCA3. Association of this condition with other severe disorders in premature newborns has not heretofore been reported. A neonatal autopsy included an in vivo whole blood sample for genetic testing. Autopsy revealed severe interstitial pulmonary fibrosis at age 8 days with heterozygotic mutation p.E292V of $\mathrm{ABCA} 3$ and severe dystrophic retardation of cerebral cortcx and cerebellum. Subsequently, 1300 archival neonatal autopsies, 1983-2006, were reviewed for comparable concurrent findings and bronchopulmonary dysplasia or retarded cerebral dystrophy lacking the other principal feature of this syndrome. Archival review revealed four similar cases and eight less so, without gene analysis. Further review for bronchopulmonary dysplasia revealed 59 cases, 1983-2006. Several other examples of similar retarded migration of germinal matrix and underdevelopment of cortical mantle, without pulmonary lesions of this type, were identified. The determination of an $\mathrm{ABCA} 3$ mutation in one case of severe pulmonary fibrosis with significant dystrophy of the brain and the identification of four highly similar archival cases and eight others with partial pathological findings supports the designation of an independent disorder, here referred to as the cerebropulmonary dysgenetic syndrome.
\end{abstract}




\section{Key Words}

Bronchopulmonary dysplasia, respiratory distress syndrome, heterozygotic mutation, retarded cortical neuronal migration, $\mathrm{ABCA} 3$ mutation, surfactant deficiency, lung fibrosis, congenital fibrosis of thyroid, cerebral dystrophy, cerebropulmonary dysgenetic syndrome

The first description and pathogenetic study of bronchopulmonary dysplasia, a complication of the evolving treatment of neonatal rcspiratory distress of the day, was forty years ago by Northway, Rosan, and Porter (1967). Interstitial pulmonary hypercellularity and progressive fibrosis were the principal features of the lung lesion when first described by them whercas others, such as Robertson $(1963,1964)$ and Barter, et al. (1966) emphasized the findings in the terminal airspaces. Indeed, Barter, et al.(1966) noted hyaline membrane formation was rarely seen in infants only four days old, describing their observations as late results.

By contrast, Northway and associates continued after 1967 to call attention to and to make further observations on the interstitial component of longer term sequelae of pressure based ventilatory support and oxygen enrichment (Northway and Rosan, 1968; Northway and Rosan, 1969; Bonikos et al., 1976; Edwards et al., 1977; Northway, 1979; Northway, 1990; Northway et al., 1990; Northway, 1992; Howling et al., 2000). An early study of the long term radiographic findings dates from 1968. (Shepard et al., 1968). Improvements in neonatal treatment since then have engendered more detailed studies of the progressive lung lesions identified in infants four to ten months old (Erickson et al., 1987) and young adult survivors (Howling et al., 2000). 
$-3-$

This more recent emphasis has overshadowed early work on the first phase of the lesion complex of hyaline membrane disease, including associated interstitial and air space hemorrhage, (Shanklin and Wolfson, 1967), and focal necrosis of terminal bronchiolar epithelium (Barter et al., 1966; Shanklin, 1971; de la Monte et al., 1986).

Evidence is now accumulating for a genetic factor in the ability of the pulmonary interstitium to respond to either the primary pathogenesis or as an adverse factor in lung healing over time, or both, specifically mutations of the gene for ATP-binding cassette transporter protein, ABCA3 (Matsumura et al., 2006; Somaschini et al., 2007; Guala et al., 2007).

This development offers an explanation for early severe onset of pulmonary fibrosis with a high failure rate in hyaline membrane disease and led, in the index case, to the discovery of another serious developmental defect, in the brain. This combination of lesions, perhaps with other associated findings, has implications challenging for diagnosis, both clinical and pathological, and neonatal intensive care, and for further research at molecular, cellular, and genetic levels.

\section{Clinical history.}

Prenatal course was normal for a 30 year old primigravida until the 34th week when labor began by premature rupture of membranes. Betamethasone and penicillin $\mathrm{G}$ were given before the spontaneous vaginal delivery, after a total labor of 18 hours. The neonatal Apgar scores were 8 at 1 minute, 9 at 5 minutes. A female infant weighed 1770 grams. Curosurf ( 1 dose) and face oxygen were provided. There was deterioration of cardioventilatory activity and she was placed on nasal CPAP, thence mechanical ventilation at 17.5 hours of life. Chest films showed hazy granular lungs with air bronchograms. Blood cultures were negative. The infant remained refractory and was transferred to 


\section{$-4-$}

our NICU on the $4^{\text {th }}$ day and placed on the oscillator. The ductus was patent with bidirectional flow by echocardiogram; there was a dilated left atrium and cardiomegaly.

Pressor support was by dopamine and dobutamine and Indocin to close the ductus ( 3 doses). Antibiotics were continued. The next four days were complicated by refractory respiratory failure, persistent hyaline membrane disease, marked hypercarbia, severe acidosis, hypotension, and secondary cardiac failure. The CRP rose $>5.0 \mathrm{mg} / \mathrm{dl}$; on the 7 th day the final WBC was $6,000 \mathrm{~mm}^{3}$. On the 8th day, tension pneumothorax occurred which was treated by drainage tube. A patient management conference with family discussed the poor prognosis: the decision was made to withdraw active support, replaced by comfort care.

Placental and autopsy findings.

The placental:fetal weight ratio was 0.197 , a median value for 34 weeks. There was generally normal development and maturation of the villi, dilation and hypertrophy of deeper vascular networks, and marginal trophoblastic hyperplasia and dccidual rcdundancy consistent with zonal placenta extrachorialis. The autopsy proper revealed: (1) unresolved somatic prematurity, (2) far advanced active progressive pulmonary fibrosis with focal remnants of hyaline membrane formation, (3) superimposed acute bronchiolitis and pneumonia, (4) myeloid hyperplasia, marrow and myeloid metaplasia, hepatic portal triads, (5) terminal systemic leukemoid reaction,

(6) advanced cortical depletion of thymus, (7) cerebrocerebellar dystrophy consisting of general retardation of cerebral glioneuroblast migration, retention of much of the paraventricular germinal matrix (with in situ maturation), stasis of proximal migratory germinal matrix, absence of protopyramidal neuronal differentiation in layer 5 of parietal (motor) cortex, neuronal 
underpopulation and immaturity of cortical mantle; dyssynchrony of purkinje cell maturation, cerebellum, with retarded development and maturation of the outer folia, and focal arteriovenous malformations in the occipital cortical and cerebellar meninges, mesencephalon, and pons, (8) biventricular myocardial hypertrophy (35\% above median value for body mass), (9) an endocrinopathy of uncertain type: retarded follicle formation, thyroid, with markedly enhanced trabecular fibrosis; eosinophile dominance, anterior pituitary; adrenal hypoplasia (combined weight, $2.8 \mathrm{~g}$, median for birth weight, $4.8 \pm 0.3 \mathrm{~g}$ ); hypoplasia of provisional adrenal cortex; hyperplasia and early maturation, adrenal medulla, and one adrenal cortical nodule. Accessory findings included patent ductus arteriosus, small focal intrafolial cerebellar hemorrhages, minimal neuronal injury, extramedullary erythropoiesis of liver and spleen, focal myelopoiesis of central axial lymph nodes, isolated thrombosis of a renal arcuate artery, thrómbosis/embolus in a marrow nutrient artery, status left post pneumothorax, and status intravascular line placements.

Specifically illustrated are the intense lung fibrosis (Figure 1), the remnants of germinal matrix and in situ maturation (Figure 2), the immature parietal cortex lacking pyramidal cells in layer 5 (Figure 3), and trabecular fibrosis of an immature, likely hypofunctional thyroid (Figure 4).

\section{Genetic report.}

From Ambry Genetics (Aliso Viejo, CA): heterozygotic mutation of ABCA3 full gene, known mutation p.E292V, the same mutation found in case \#8 of Somaschini, et al. (2007), in 10 of 11 patients reported by Bullard, et al. (2005) but not by Matsumura, et al.(2006) or Shulenin, et al.(2004).

No novel or other reported variants were identified. 


\section{Archival investigation.}

Twelve cases with lung and brain findings similar to those of the index case were identified over the interval 1991-2006; four of these had many aspects in common (Table 1). A fifth archival case with birth weight of $3368 \mathrm{~g}$ at 41 weeks survived 21 days. The lung showed massive superimposed lobular pneumonia and hemorrhage on $1+$ bronchopulmonary dysplasia. There was gyromantle dysplasia with indistinct cortical layers, macrogyria, gliofibrillary meningeal nodules, bilateral narrow lateral dimension of basal ganglia, and far advanced fibrous septation of the thyroid with mixed collections of follicles typical of colloid goiter and others tightly compressed by the fibrosis. This case showed no remnant germinal matrix and was at term, suggestive of a major disturbance later in the migratory process. The greater maturity and prolonged survival prompted our determination not to include it in the table of principal cases.

In addition, a survey from the archives for 1983-2006 located 59 additional cases of bronchopulmonary dysplasia in 660 neonatal and infant autopsies (total database including stillborns, 1983-2006, 1280 autopsies with complete examination of the central nervous system), for a total of $71(10.76$ per cent). The proportion of cases of pulmonary fibrosis putatively affected by $\mathrm{ABCA} 3$ mutations, from this perspective, is a remarkable 16.9 per cent, not a trivial subset of infants. Eight additional cases of comparable cerebrocerebellar dystrophy, without lung fibrosis, were found in this survey. While a small number, it is sufficient to suggest the possibility of multigenic effects interrelating these lesions and susceptibilities. 


\section{DISCUSSION}

This is a seeming case of first impression. The many complexities can be brought together as a condition here designated as the cerebropulmonary dysgenetic syndrome, on a provisional basis. Information now available in the medical and genetical literature makes it possible to establish a connection between two severe pathological disorders in premature newborns:

1. Advanced and progressive pulmonary fibrosis, the late stage of hyaline membrane disease, well described as bronchopulmonary dysplasia.

2. Maturational discordance in the central nervous system, more especially migrational delay from the germinal matrix with neuronal underpopulation of the cortical mantle as a principal result. Associated is persistent paraventricular germinal matrix per se, with variable amounts of bulk migratory cells not far from their origin in the matrix, and, most remarkable, maturation of matrix in situ.

The link between these seemingly disparate devastations of key tissues in the newborn infant lies with the demonstration of a $\mathrm{ABCA} 3$ heterozygotic mutant status in this case. $\mathrm{ABCA} 3$ is one member of the ATP-binding casette transporter family A3, an important group of substance transport molecules (Dean et al., 2001). Mutations in the ABCA3 gene have been identified as a principal factor in fatal neonatal surfactant deficiency (Shulcnin et al., 2004; Bullard et al., 2005). Moreover, the ABCA3 mutants have been well characterized, classified, and localized in type 2 pneumocytes which produce surfactant, (Matsumura et al., 2006), thus setting the cellular stage for the depletion of stored surfactant following the challenge of initial lung expansion (Bolande and Klaus, 1964), with an inability to replenish the surfactant. In addition, LBM180, a lamellar body limiting membrane protein of type 2 pneumocytes, has been identified as ABCA3 transporter protein 
(Mulugeta et al., 2002). This finding solidifies the relationship of the protein to lung disorders common to premature newborns.

The link between the pulmonary disorder and the abnormal brain lies in some exacting work on the brain of the developing mouse which establishes an abundance of the ABCA3 protein in cortical mantle(Tachikawa et al., 2005), sometimes referred to in the fetal mouse as the differentiating zone. $\mathrm{ABCA} 3$ is also found throughout the early brain, but is not upregulated post natally in the white matter after the migration is completed (Tachikawa et al., 2005).

The superfamily of human $\mathrm{ABC}$ genes is complex with expression of $A B C A 3$ in lung and that of $A B C A 2$ in brain (Dean et al., 2001). $A B C A 2$ and $A B C A 3$ are closely related in subgroup ABCA-I (Dean et al., 2001). The ABCA3 sequence is highly conserved in humans, rats, and mice in the region of the E292V mutation (Bullard et al., 2005), enhancing the validity of applying the results of Tachikawa, et al (2005) in mice to the scope of disorders here described as the cerebropulmonary dysgenetic syndrome.

We have observed the unusual fibrous trabeculation of the thyroid occasionally but not systematically. Abnormal thyroid development and poor function were described in instances of global cerebral malformation by Shanklin (1991), offering the possibility of more than one factor at work in the endocrinopathy seen in our index case and in several from archival review.

The genetic mutation behind this pathogenesis has been attributed to an autosomal recessive state in a study on 12 newborns (Guala, et al., 2007). By contrast, another report of similar size 


\section{-9-}

(Somaschini, et al., 2007), identified three of 14 as heterozygotic mutants [their patients 7, 8, and 13]. Bullard, et al. (2005), described three older individuals (ages 11,16 , and 23 years) with the same missence mutation, E292V, found in our index patient, with a second mutation. These three patients has interstitial lung disease at their much later stage of life (Bullard, et al., 2005). These seeming discrepancies are evidence for compounded or multifactorial pathogenesis which may include such counterintuitive results as an autosomal dominant variant of the Wiskott-Aldrich syndrome, classically understood to be an X-linked recessive disease (Rocca, et al., 1996). It may be that certain regulatory proteins have to present in both parental genomes for proper function in the offspring. A variant allele through mutation can be sufficient to create an abnormal phenotype in that the haploid state of the wild type allele is inadequate for normal function. This is the case for a number of disorders. Women with heterozygous $\alpha$-galactosidase mutations (Fabry disease) suffer from significant multisystemic disease, resulting in a reduced quality of life (Wang, et al., 2007). Wang and associates studied 44 heterozygous women, a majority referred due to an affected male relative, of whom about $75 \%$ reported acroparesthesias as their first symptom (Wang, et al., 2007). Other symptoms were prominent such as fatigue with reduced oxygen consumption, exercise intolerance with low heart rate during exercise testing, and angina, symptoms characteristic of the homozygous state (Wang, et al., 2007). Comparable confounding heterozygotic abnormalities have been described for fanilial hypobetalipoproteinemia (Alapont Puchalt, et al., 2004). Perhaps the best example of enhanced risk for disease manifestations from the heterozygous mutant state is factor V Leiden (Glucck, et al., 2007; Herman, et al., 2006; Imperialc, ct al., 2007;Kalajian, et al., 2007; Marchiori, et al., 2007; Verdu, et al., 2005). Marchiori, et al. (2007) estimated risk ratios on the order of 1.39 to 1.45 , which, considering the tendency for this trait to become manifest in 
pregnancy, is an important health problem. At a fundamental cellular level, DNA polymerase $\beta$, carries out base excision repair necessary for DNA maintenance (Bhattacharyya and Banerjee, 1997). A variant polymerase from deletion in the 87 -bp region, in the heterozygous state, results in cells incapable of base excision repair and highly sensitive to the known group $2 \mathrm{~A}$ animal carcinogen, $N$-methyl-N'-nitro- $N$-nitrosoguanidine (Bhattacharyya and Banerjee, 1997; Fujii and Nakadate, 1977).

The index case in this report serves to suggest more frequent genctic testing in the clinical scenario of early bronchopulmonary dysplasia in premature newborns will provide necessary data by which to assess the prevalence of this potential complication of neonatal care. The archival cases reported here are a window onto new aspects of development of the human fetal brain. There are now four well documented examples of severe bronchopulmonary dysplasia related to heterozygous mutations in the ABCA3 transporter protein gene (Somaschini, et al., 2007 and this casc). The existence of an increasing number of instances where the heterozygous state carries significant risk burdens (as cited above) is a compelling argument for further study and clarification of the risk and the processes by which these disorders are manifested.

\section{Author's statements}

All authors performed the autopsy mentioned and participated in the original report thereon. The corresponding author wrote the first dran of this submission and the final version contains important input from all authors. The illustrations were taken by the corresponding author. There are no interests to be disclosed. Funding is entirely inhouse as part of routine departmental diagnostic work.

Total word count (including these lines) of text, references, and legends $=3660$ Total word count in the abstract $=198$ 


\section{REFERENCES}

Alapont Puchalt, B., Prosper Sierra, M., 2004. [Hepatic steatosis associated with heterozygotic familial hypobetalipoproteinemia]. Gastroenterol.Hepatol. 27, 256-259.

Barter, R.A., Byrne, M.J., Carter, R.F., 1966. Pulmonary hyaline membrane: late results of injury to the lung linings. Arch.Dis.Childh. 41, 489-495.

Bhattacharyya, N., Banerjee, S., 1997. A variant of DNA polymerase $\beta$ acts as a dominant negative mutant. Proc.Natl.Acad.Sci.USa 94, 10324-10329.

Bolande, R.P., Klaus, M.H., 1964. The morphologic demonstration of an alveolar lining layer and its relationship to pulmonary surfactant. Am.J.Pathol. 45, $449-463$.

Bonikos, D.S., Bensch, K.G., Northway, W.H., Edwards, D.K., 1976. Bronchopulmonary dysplasia: the pulmonary pathologic sequel of necrotizing bronchiolitis and pulmonary fibrosis.

Hum.Pathol. 7, 643-666.

Bullard, J.E., Wert, S.E., Whitsett, J.A., Dean, M., Nogee, L.M., 2005. ABCA3 mutations associated with pediatric interstitial lung disease. Am.J.Respir.Crit.Care Med. 172, 1026-1031.

Dean, M., Rzhetsky, A., Allikmets, R., 2001. The human ATP-binding cassette (ABC) transporter superfanily. Genome Res. 11, 1156-1166.

de la Monte, S.M., Hutchins, G.M., Moore, G.W., 1986. Respiratory epithelial cell necrosis is the earliest lesion of hyaline membrane disease of the newborn. Am.J.Pathol. 123, 155-160.

Edwards, D.K., Dyer, W.M., Northway, W.H., 1977. Twelve years' experience with bronchopulmonary dysplasia. Pediatrics 59, 839-846.

Erickson, A.M., de la Monte, S.M., Moore, G.W., Hutchins, G.M., 1987. The progression of morphologic changes in bronchopulmonary dysplasia. Am.J.Pathol. 127, 474-484.

Fujii, K., Nakadate, M., 1977. Tumor induction by a single subcutaneous injection of $N$-methyl- $\mathrm{N}^{\prime}-$ nitro- $N$-nitrosoguanidine and its derivatives in newborn mice. Z.Krebsforsch. 90, 313-319.

Glueck, C.J., Tracy, T., Wang, P., 2007. Legg-Calve-Perthes disease, venous and arterial thrombi, and the factor V Leiden mutation in a four-generation kindred. J.Pediatr.Orthop. 27, 834-837.

Guala, A., Carrera, P., Pastore, G., Somaschini, M., Ancora, G., Faldella, G., De Filippi, P., Ferrero, F., Guarino, R., Danesion, C., 2007. Familial clustering of unexplained transient respiratory distress in 12 newborns from three unrelated families suggests an autosomal-recessive inheritance. Scient.World J. 7,1611-1616. 
Herman, M., Djelmis, J., Troselj, Z., Ivanisevuc, M., 2006. [Pregnancy outcomes in a patientheterozygous carrier of R506Q mutation of factor V (Leiden)]. Acta Med.Croatica. 60, 277-280.

Howling, S.J., Northway, W.H., Hansell, D.M., Moss, R.B., Ward, S., Müller, N.L., 2000. Pulmonary sequelae of bronchopulmonary dysplasia survivors: High-resolution CT findings. AJR $174,1323-1326$.

Imperiale, D., Cassano, D., Pomari, F., Cecchi, E., Cerrato, P., Buffa, C., 2007. Ischaemic stroke, factor V Leiden heterozygosity and left atrial thrombosis in sinus rhythm: a case report. Neurol.Sci. $28,111-113$.

Kalajian, A.H., Turpen, K.B., Donovan, K.O., Malone, J.C., Callen, J.P., 2007. Phenylephrineinduced microvascular occlusion syndrome in a patient with a hetcrozygous factor $\mathrm{V}$ Leiden mutation. Arch.Dermatol. 143, 1314-1317.

Marchiori, A., Mosena, L., Prins, M.H., Prandoni, P., 2007. The risk of recurrent venous thromboembolism among heterozygous carrier of factor V Leiden or prothombin G20210A mutation. Haematologica 92, 1107-1114.

Matsumura, Y., Ban, N., Ueda, K., Inagaki, N., 2006. Characterization and classification of ATP-binding cassette transporter ABCA3 mutants in fatal surfactant deficiency. J.Biol.Chem. 281, $34503-34514$.

Mulugeta, S., Gray, J.M., Notarfrancesco, K.L., Gonzales, L.W., Koval, M., Feinstein, S.I., Ballard, P.L., Fisher, A.B., Shuman, H., 2002. Identification of LBMI80, a lamellar body limiting membrane protein of alveolar type II cells, as the $\mathrm{ABC}$ transporter protein ABCA3. J.Biol.Chem. $277,22147-22155$.

Northway, W.H., Rosan, R.C., Porter, D.Y., 1967. Pulmonary disease following respirator therapy of hyaline membrane disease; bronchopulmonary dysplasia. New Engl.J.Med. 276, $357-368$.

Northway, W.H., Rosan, R.C., 1968. Radiographic features of pulmonary oxygen toxicity in the newborn: Bronchopulmonary dysplasia. Radiology 91, 49-58.

Northway, W.H., Rosan, R.C., 1969. Treatment of hyaline-membrane disease. New Engl.J.Med. 280,331 .

Northway, W.H., 1979. Observations on bronchopulmonary dysplasia. J.Pediat. 95, 815 -818.

Northway, W.H., 1990. Bronchopulmonary dysplasia: then and now. Arch.Dis.Childh. 65, 1076 -1081 .

Northway, W.H., Moss, R.B., Carlisle, K.B., Parker, B.R., Popp, R.L., Pitlick, P.T., Eichler, I., Lamm, R.L., Brown, B.W., 1990. Late pulmonary sequelae of bronchopulmonary dysplasia. New Engl.J.Med. 323, $1834-1836$. 
Northway, W.H., 1992. Bronchopulmonary dysplasia: twenty-five years later. Pediatrics

89 , $969-973$.

Robertson, B. 1963 The relationship between hyaline membranes of the newborn and the presence of other pulmonary lesions. Acta Paediatrica 52, $569-574$.

Robertson, B., 1964. Pulmonary hyaline membranes of the newborn; The structure of the membranes at varying postnatal age. Acta Path.Microbiol.Scandinav. 62, $581-588$.

Rocca, B., Bellacosa, A., De Cristofaro, R., Neri, G., Della Ventura, M., Maggiano, N., Rumi, C., Landolfi, R., 1996. Wiskott-Aldrich syndrome: report of an autosomal dominant variant. Blood $87,4538-4543$.

Shanklin, D.R., Wolfson, S.L., 1967. Therapeutic oxygen as a possible cause of pulmonary hemorrhage in premature infants. New Engl.J.Med. 277, $833-837$.

Shanklin, D.R., 1971. Oxygen and the lungs of newborn infants. Int.J.Clin.Pharm. 5, 20 -25.

Shanklin D.R., 1991. Pathologic studies of fetal thyroid development. In: Becu BB, Shulman DI, eds. Advances in perinatal thyroidology. Adv.Exp.Med.Biol. 299, $27-46$.

Shepard, F.M., Johnston, R.B.,Jr, Klatte, E.C., Burko, H., Stahlman, M., 1968. Residual pulnonary findings in clinical hyaline-membrane disease. New Engl.J.Med. 279, $1063-1071$.

Shulenin, S., Nogee, L.M., Annilo, T., Wert, S.E., Whitsett, J.A., Dean, M., 2004. $A B C A 3$ gene mutations in newborns with fatal surfactant deficiency. New Engl.J.Med. 350, 1296-1303.

Somaschini, M., Nogee, L.M., Sassi, I., Danhaive, O., Presi, S., Boldrini, R., Montrasio, C., Ferrari, M., Wert, S.E., Carrera, P., 2007. Unexplained neonatal respiratory distress due to congenital surfactant deficiency. J.Pediat. 150, 649-653.

Tachikawa, M., Watanabe, M., Hori, S., Fukaya, M., Ohtsuki, S., Asashima, T., Terasaki, T., 2005. Distinct spatio-temporal expression of ABCA and ABCG transporters in the developing and adult mouse brain. J.Neurochemistry 95, 294-304.

Verdu, A., Cazorla, M.R., Moreno, J.C., Casado, L.F., 2005. Prenatal stroke in a neonate heterozygous for factor V Leiden mutation. Brain.Dev. 27, 451-454.

Wang, R.Y., Lelis, A., Mirocha, J., Wilcox, W.R., 2007. Heterozygous Fabry women are not just carriers, but have a significant burden of disease and impaired quality of life. Genet.Med. 9, 34-45. 


\section{LEGEND FOR TABLE}

Table 1: Comparison of findings, index and archival cases.

\section{LEGENDS FOR FIGURES}

All photographs are of tissues stained by hematoxylin and cosin; original magnifications, $100 \mathrm{X}$.

Figure 1: Representative pulmonary lobule with extensive advanced fibrosis, mononuclear cell proliferation, and disordered vascular pattern. There are no competent peripheral air spaces and rare terminal bronchioles (not shown). This pattern was found throughout all five pulmonary lobes.

Figure 2: Paraventricular germinal matrix, midzone, with irregular remnant clusters of primitive glioneuroblasts mingled with neural cell maturation in situ. Similar masses of immature migratory cells were in stasis adjacent to and occasionally surrounding blood vessels in the influence of the middle cerebral arteries.

Figure 3: Representative zone of parietal motor cortex. Layers of the cortical mantle are poorly arrayed; the locus of layer 5 , across the middle of the view, lacks defined pyramidal and protopyramidal neurons. These are usually conspicuous by $30-31$ weeks gestational age.

Figure 4: Thyroid gland marked by dense interlacing fibrous septa which surround poorly developed follicles lacking colloid normally present at a gestational age of 34 weeks. 


\begin{tabular}{|c|c|c|c|c|c|}
\hline Case & Index & Archive-1 & Archive-2 & Archive-3 & Archive-4 \\
\hline Gestation & 34 weeks & 26 weeks & 25 weeks & 32 weeks & 28 weeks \\
\hline Birth wt. & $1770 \mathrm{~g}$ & $699 \mathrm{~g}$ & $620 \mathrm{~g}$ & $951 \mathrm{~g}$ & $942 \mathrm{~g}$ \\
\hline Survival & 8.3 days & 10.0 days & 26 days & 18 days & 57 days \\
\hline Lung & $\begin{array}{l}4+ \\
\text { fibrosis }\end{array}$ & $\begin{array}{l}4+ \\
\text { fibrosis }\end{array}$ & $\begin{array}{l}4+ \\
\text { fibrosis, } \\
\text { leimyoma- } \\
\text { tosis }\end{array}$ & $\begin{array}{l}1+\text { with } \\
\text { remnant } \\
\text { hyaline } \\
\text { membranes } \\
\text { and } \\
\text { infarcts }\end{array}$ & $\begin{array}{l}2+\text { with } \\
\text { superim- } \\
\text { posed } \\
\text { necroti- } \\
\text { zing } \\
\text { pneumonia }\end{array}$ \\
\hline $\begin{array}{l}\text { Germinal } \\
\text { matrix } \\
\text { delay }\end{array}$ & $\begin{array}{l}\text { Marked, } \\
\text { extensive }\end{array}$ & $\begin{array}{l}\text { Little } \\
\text { migration } \\
\text { beyond GM }\end{array}$ & $\begin{array}{l}\text { GM hemor- } \\
\text { rhage and } \\
\text { rupture }\end{array}$ & $\begin{array}{l}\text { Gliofib- } \\
\text { rillary } \\
\text { nodules, } \\
\text { clusters }\end{array}$ & $\begin{array}{l}\text { Remnant } \\
\text { almost } \\
\text { without } \\
\text { migration }\end{array}$ \\
\hline $\begin{array}{l}\text { Cortical } \\
\text { mantle }\end{array}$ & $\begin{array}{l}\text { Poorly } \\
\text { layered, } \\
\text { under- } \\
\text { populated }\end{array}$ & $\begin{array}{l}\text { Much } \\
\text { retarded, } \\
\text { focal } \\
\text { dysplasia }\end{array}$ & $\begin{array}{l}\text { Retarded, } \\
\text { zones of } \\
\text { discor- } \\
\text { dancy }\end{array}$ & $\begin{array}{l}\text { Immature, } \\
\text { no layer } \\
5 \text { neurons }\end{array}$ & $\begin{array}{l}\text { Cortical } \\
\text { dysplasia } \\
\text { and poor } \\
\text { layers }\end{array}$ \\
\hline Thyroid & $\begin{array}{l}\text { Dense } \\
\text { fibrous } \\
\text { septation }\end{array}$ & $\begin{array}{l}\text { Fibrocys- } \\
\text { tic } \\
\text { dysplasia }\end{array}$ & $\begin{array}{l}\text { Slow } \\
\text { develop- } \\
\text { ment }\end{array}$ & $\begin{array}{l}\text { No lesion } \\
\text { recorded }\end{array}$ & $\begin{array}{l}\text { No lesion } \\
\text { recorded }\end{array}$ \\
\hline Adrenal & $\begin{array}{l}\text { Small, } \\
\text { meduliary } \\
\text { maturity, } \\
\text { adenoma } \\
\text { next to } \\
\text { capsule }\end{array}$ & $\begin{array}{l}\text { Neural } \\
\text { crest } \\
\text { delay }\end{array}$ & $\begin{array}{l}\text { Adrenal } \\
\text { rest in } \\
\text { hilum of } \\
\text { testis }\end{array}$ & $\begin{array}{l}\text { Slow post } \\
\text { natal in- } \\
\text { volution, } \\
\text { fetal } \\
\text { zone }\end{array}$ & $\begin{array}{l}\text { Fetal } \\
\text { cortical } \\
\text { involu- } \\
\text { tion com- } \\
\text { plete for } \\
\text { age }\end{array}$ \\
\hline Pituitary & $\begin{array}{l}\text { Eosino- } \\
\text { philia }\end{array}$ & $\begin{array}{l}\text { Eosino- } \\
\text { philic } \\
\text { nodule }\end{array}$ & $\begin{array}{l}\text { Normal } \\
\text { for age }\end{array}$ & $\begin{array}{l}\text { Normal } \\
\text { for age }\end{array}$ & $\begin{array}{l}\text { Normal } \\
\text { for age }\end{array}$ \\
\hline
\end{tabular}




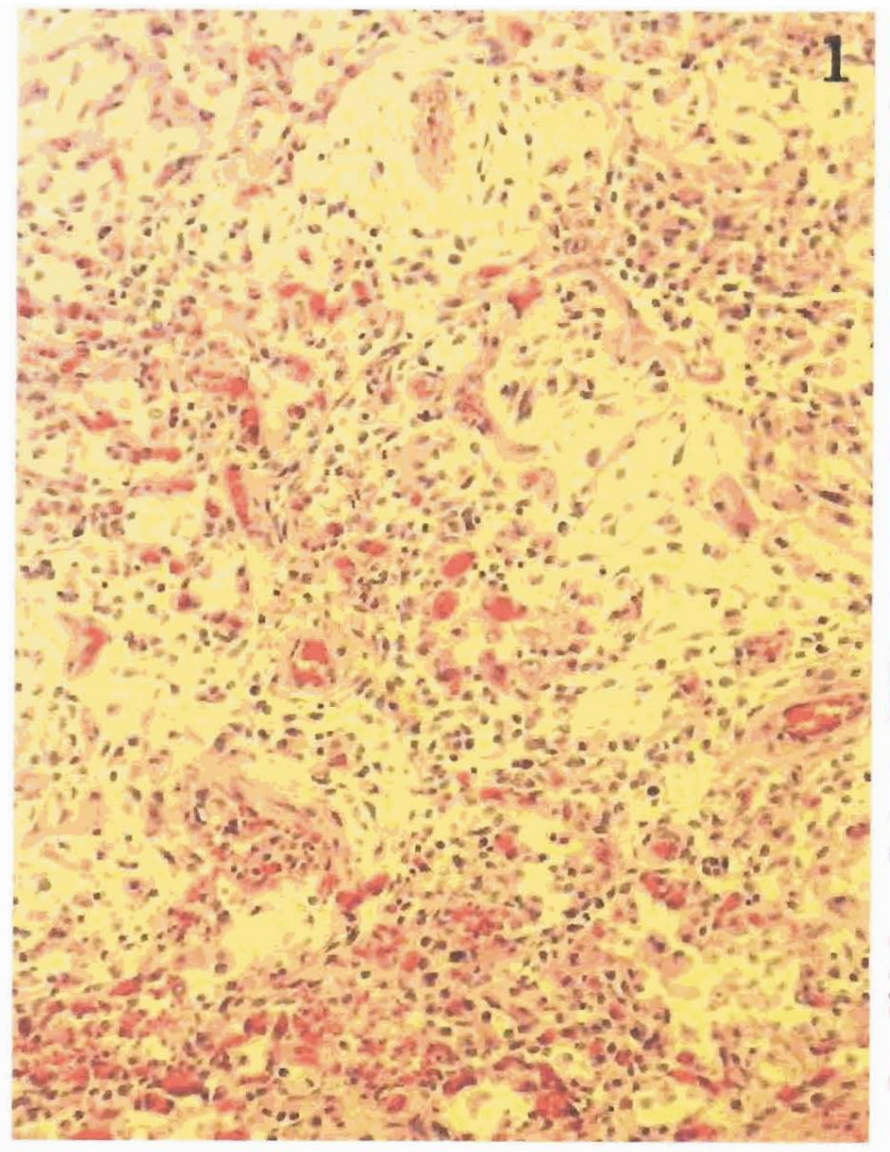

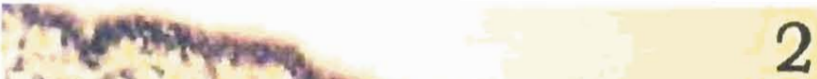

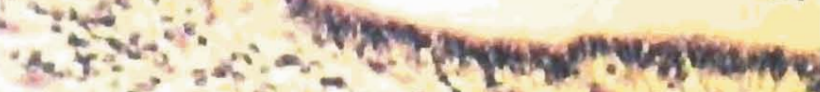

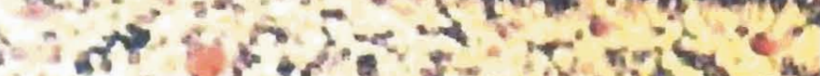

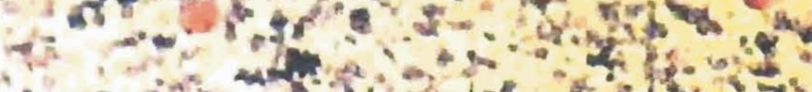

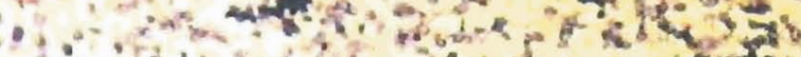

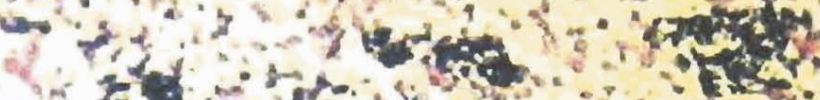

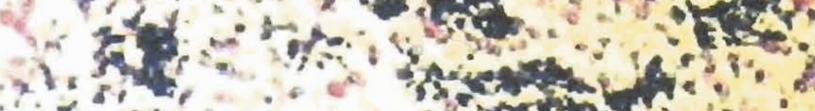

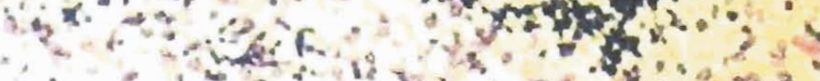

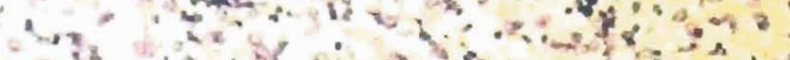
is $=2$ on

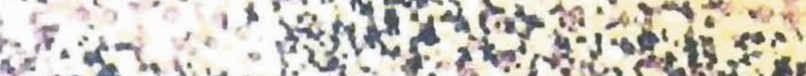
and

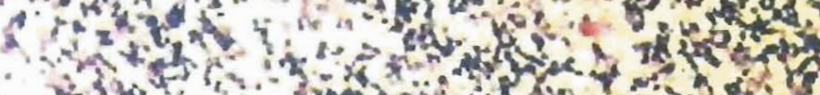
Pें ingang

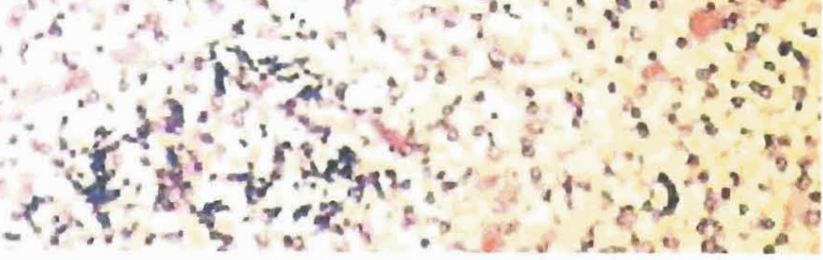

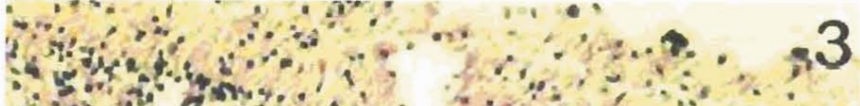

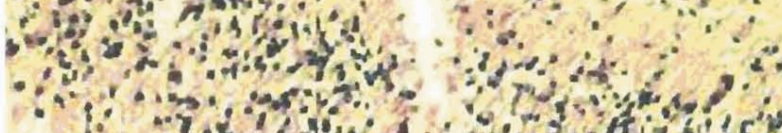

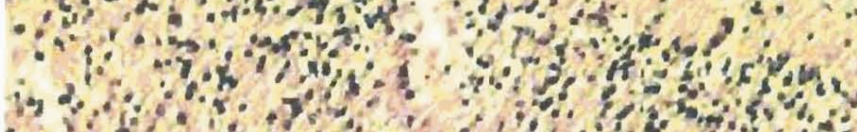

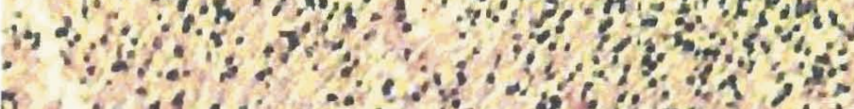

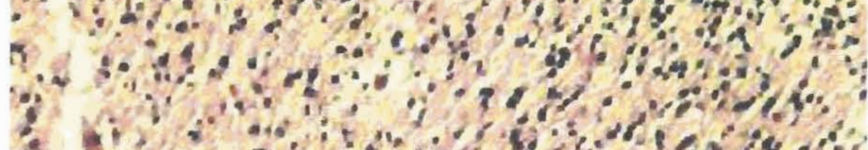

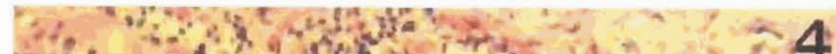

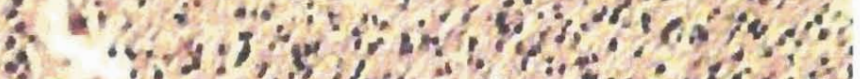
$80 \%$ क

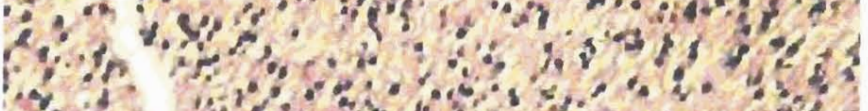

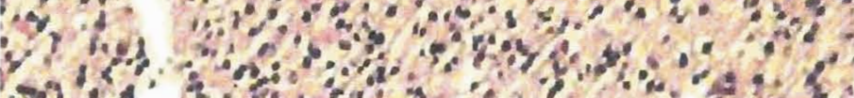
$-23^{3}$ ? at

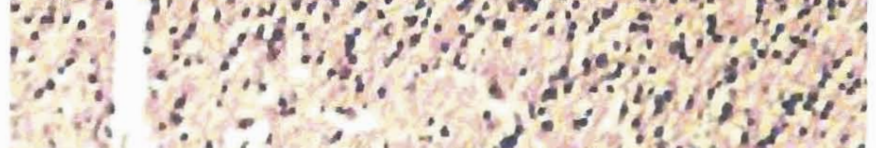

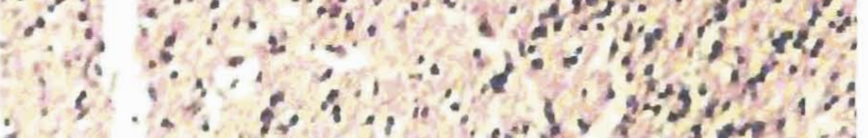

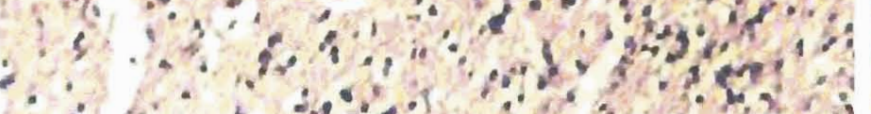

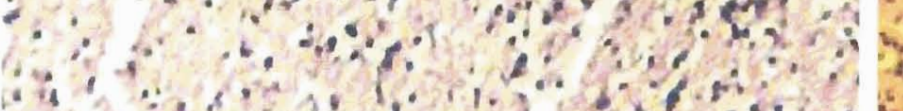

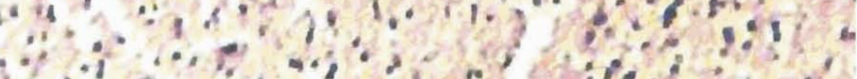

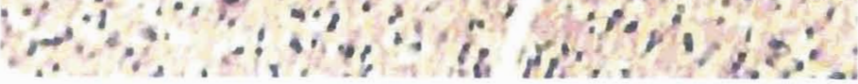

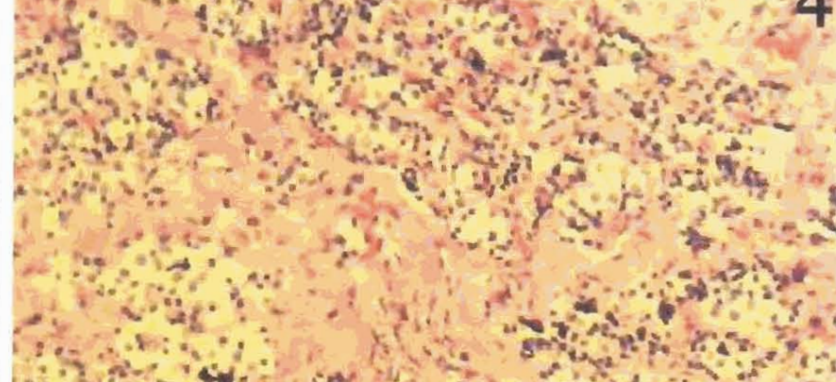

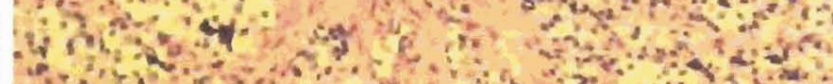
Ex

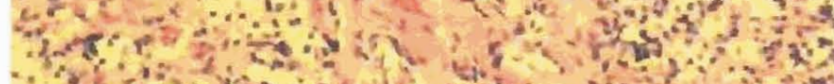
स.

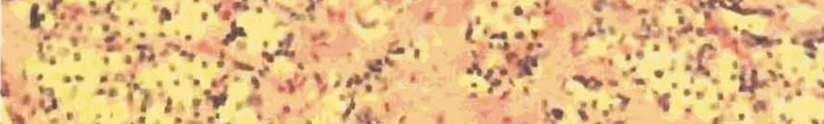
$\therefore$ The

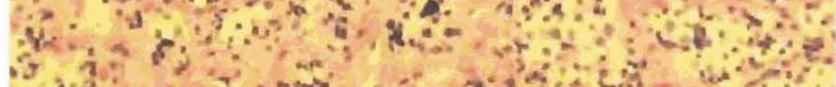

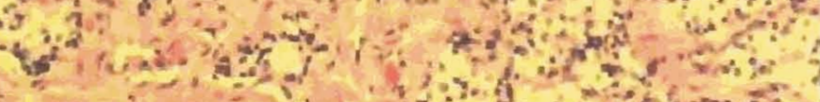

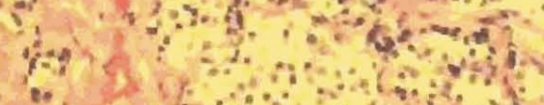

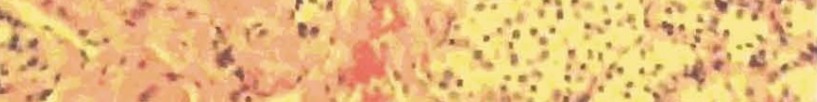

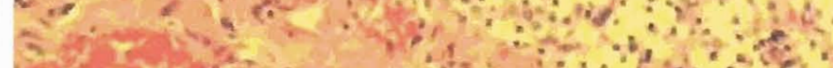

